\title{
EFFECT OF CYANOBACTERIA, AND PHOSPHATE DISOLING BACTERIA INOCULATION ON IMPROVING PEANUT PRODUCTIVITY IN PRESENCE OR ABSENCE OF DIFERENT RATES OF ROCK PHOSPHAE FERTILIZER UNDER SANDY SOIL CONDITION

\author{
Ahmed, S. M.; G. A. M. EL- Sayed; F. M. Ghazal and
} Sh. M. Abd EL-Rasoul

Soils, Water and Environment Res. Inst. (SWERI), Agric. Res. Center (ARC), Giza, Egypt

\begin{abstract}
A field experiment was carried out in a sandy soil at EL- Ismailia Agric. Res. Station, EL- Ismailia Governorate, (A R C), Giza, Egypt, during the summer season of 2005 to study the effect of inoculation with cyanobacteria and phosphate dissolving bacteria (PDB) viz. Bacillus megatherium var. phosphaticum, each alone or both in combination andlor when the inoculation was accompanied with different rates of rock phosphate fertilizer as a natural source of phosphorus on peanut productivity, NP\&K uptake of peanut seeds and foliage and the soil total count bacteria, actinomycetes and fungi. Results revealed that inoculation with cyanobacteria andlor PDB each alone or both in combination increased peanut pods weight, seeds and foliage yields, $\mathrm{N}, \mathrm{P}$ and $\mathrm{K}$ contents for both peanut seeds and foliage compared to uninoculated treatments. Also, the combination of both microbial inoculation and rock phosphate fertilizer at any rate increased significantly these parameters than those received either inoculation or rock phosphate each alone. At flowering stage, generally, the inoculation with either cyanobacteria or Bacillus andlor their combination increased the soil total count of bacteria, actinomycetes and fungi compared to those recorded by uninoculated treatments and those recorded initially and harvest for all the other tested treatment. Generally, the use of $600 \mathrm{~kg} \mathrm{fed}^{-1}$ rock phosphate fertilizer along with inoculation with cyanobacteria and Bacillus was superior to those received microbial inoculation only, or rock phosphate fertilizer at the rates of 200 and $400 \mathrm{~kg} \mathrm{fed}^{-1}$ only andlor their combination with dual inoculation with cyanobacteria and Bacillus. This microbial inoculation/rock phosphate integration helps in the fast solubilization of the insoluble phosphate found in rock phosphate that may lead to reduce the cost and the environmental pollution due to the extensive use of the mineral fertilizers.
\end{abstract}

\section{INTRODUCTION}

Peanut (Arachis hypogaea L.) is considered one of the most important legumeous and oil seed crops, which are cultivated and thrive in the newly reclaimed sandy soils in Egypt (Rashid and Ryan, 2004)..

The Egyptian deserts are wide extensions representing about $94 \%$ of the total area of Egypt. The remaining area represents about $6 \%$ of the total area is considered for agriculture and foundations. According to the annual increase of the Egyptian population, it requires tremendous efforts to increase food production. The government aims toward reclaiming desert area along both sides of the River Nile. The soils of these areas are mainly sands and need organic and inorganic fertilizers to improve their properties for agriculture use. 
Ahmed, S. M. et al.

The drastic raising in the chemical fertilizer prices and their adverse effects on environment greatly incited the serious endeavors of many researchers to seek the relevant alternatives of synthetic fertilizers. These may be involving the extension in the practice of sustainable agriculture system, which relies mainly on the legume-Rhizobium symbiosis (Jensen and Hauggaard, 2003) in addition of utilizing the natural materials as sources of macro and micronutrients such as rock-phosphate, dolomite, feldspar, crushed lime stone and gypsum with efficient inoculants and organic materials (Conacher and Conacher, 1998; Abdel-Wahab et al., 2003 and Mekhemar et al., 2007).

Mineral nutrients deficiencies are major constraints limiting legume nitrogen fixation and yield (O'Hara et al., 1988). Among the necessary nutrients, legumes need relatively large amounts of phosphorus Nodules formation and function are both adversely affected with phosphorus deficiencies (Van Schreven, 1958). However, phosphorus application gave a highly significant increase in faba bean yield (Hussein et al., 1993). Also, it is very important element to plant growth and plays a key role in metabolic processes such as the conversion of sugar into starch and cellulose (Mengel and Kirkby, 1987). It is a constituent of nucleic acids (DNA and RNA) and is considered as a high strong energy compound (Miller and Donahue, 1995), stimulate, cell division and enhance root growth, nodulation and $\mathrm{N}_{2}$-fixation (Knany et al., 2004).

Biological fertilization becomes an important factor in increasing availability of $P$ and micronutrients as well as to improve their plant uptake. El-Habbasha et al. (2005) reported that phosphate dissolving bacteria has an important role in solubilizing of $P$ and its absorption which, in turn, improves seed germination and yield of plant, which could be attributed mainly to $\mathrm{N}_{2}-$ fixation. There is a report for Hedge et al. (1999) who noted that cyanobacteria also have some soil phosphate solubilizing species.

The current work aims to evaluate the effect of inoculation with cyanobacteria and phosphate dissolving bacteria (PDB) viz. Bacillus megatherium var. phosphaticum, each alone or both in combination andlor when the inoculation was accompanied with different rates of rock phosphate fertilizer as a natural source of phosphorus on peanut productivity, NP\&K percentages of peanut seeds and foliage and the soil total count bacteria, actinomycetes and fungi.

\section{MATERIALS AND METHODS}

A field experiment was carried out in a sandy soil at EL- Ismailia Agric. Res. Station during the summer season of 2005 to study the effect of inoculation with cyanobacteria and phosphate dissolving bacteria (PDB) viz. Bacillus megatherium var. phosphaticum, each alone or both in combination andlor when the inoculation was accompanied with different rates of rock phosphate fertilizer as a natural source of phosphorus on peanut productivity, NP\&K uptake of peanut seeds and foliage and the soil total count bacteria, actinomycetes and fungi. 
The main physical and chemical properties of the experimental soil and the analyses of the organic compost are presented in Tables (1 \& 2), and determined according to the standard methods described by Jackson (1976) and Page et al. (1982).

The experimental design was split-plot with three replicates, where the main plots were assigned to rates of Rock phosphate (PR) as follows:

1- Control (without RP)

2- Rock phosphate at the rate of $200 \mathrm{~kg} / \mathrm{fed}(\mathrm{RPI})$.

3- Rock phosphate at the rate of $400 \mathrm{~kg} / \mathrm{fed}$ (RPII).

4- Rock phosphate at the rate of $600 \mathrm{~kg} / \mathrm{fed}$ (RPIII).

The sub plots were inoculation with bacteria as follows:-

1- $A=$ Control without inoculation

2- $\mathrm{B}=$ Cyanobacteria

3- $\mathrm{C}=$ phosphate dissolving bacteria.

4- $\mathrm{D}=$ Cyanobacteria + phosphate dissolving bacteria.

The plot area was $3 \mathrm{~m} \times 3.5 \mathrm{~m}=10.5 \mathrm{~m}^{2}$ (1/400 fed.).

Peanut (Arachis hypogaea L.) seed cv. Giza 6 was sowed in hills at 20 $\mathrm{cm}$ apart on rows of $60 \mathrm{~cm}$ apart, sprinkler irrigation was carried out four days intervals.

The recommended chemical fertilizers were applied at rates of 40,15 and $24 \mathrm{~kg}$ for $\mathrm{N}, \mathrm{P}_{2} \mathrm{O}_{5}$ and $\mathrm{K}_{2} \mathrm{O}$ per faddan, in the form of ammonium sulphate $(20.5 \% \mathrm{~N})$, superphosphate $\left(15.5 \% \mathrm{P}_{2} \mathrm{O}_{5}\right)$ and potassium sulphate $\left(48 \% \mathrm{~K}_{2} \mathrm{O}\right)$, respectively. Both phosphorus and potassium were added before sowing, while nitrogen was added after 10 days from planting. Cyanobacteria at the rate of $10 \mathrm{~kg} \mathrm{fed}^{-1}$ were inoculated to peanut seeds using the soil based inoculum $\left(10^{9} \mathrm{cfu} \mathrm{g} \mathrm{soil}^{-1}\right)$ cyanobacteria. The cyanobacteria inoculum was prepared according to the method described by Venkataraman (1972). The Inoculum containing the following cyanobacteria strains ,i.e., Nostoc muscorum, Nostoc calcicola, Anabaena oryzae and Clyndrospermum muscicola. While, Bacillus megatherium var. Phosphaticum supplied by Department of Microbiology, SWERI, ARC, Giza, was the phosphate dissolving bacteria inoculum. Vermiculate supplemented with 10\% Iresh peat was packed in polyethylene bag (300 g carrier per bag), then sealed and sterilized by gamma irradiation ( $5 \times 10^{6}$ rads). The carrier bags were injected with Bacillus megatherium var. Phosphaticum $\left(5 \times 10^{8} \mathrm{cfu} / \mathrm{mL}\right)$ culture to satisfy $60 \%$ of the maximal water holding capacity. Cyanobacteria inoculum was applied after three weeks from sowing, while phosphate dissolving bacteria inoculum was applied to peanut seeds before sowing by seed coating using Arabic gum as an adhesive agent.

All agricultural practices were carried out as recommended in this district by the Egyptian Ministry of Agriculture and Land Reclamaition. Soil was sampled at different intervals, i.e., initial time, flowering time and at harvest to determine total bacteria count (Allen, 1959), total Actinomycetes count (Williams and Davis, 1965) and total fungi count (Martin. 1950) as index for soil biological activity.

At maturity, plants were picked, pods were separated, air dried, weighted and pealed into seeds and husks. Samples of seeds and foliage were oven dried, weighed and ground. N, P and $\mathrm{K}$ content in both seed and 
Ahmed, S. M. et al.

foliage were determined according to methods mentioned by Chapman and Pratt (1961) and Jackson (1976).

All obtained data were statistically analyzed according to Gomez and Gomez (1984).

Table (1): Some physical and chemical properties for the experimental soil

\begin{tabular}{|l|c|c|c|}
\hline Properties & Value & Properties & Value \\
\hline Particle size distribution \% & 10.25 & $\begin{array}{c}\text { Chemical analysis } \\
\text { PH (1:2.5) }\end{array}$ & 7.7 \\
Coarse sand & 79.20 & $\mathrm{EC} \mathrm{dSm}$ & 1.1 \\
Fine sand & 5.15 & Soluble ions (meq/l) & \\
Silt & 5.40 & $\mathrm{Ca}^{++}$ & 4.10 \\
Clay & sandy & $\mathrm{Mg}^{++}$ & 2.00 \\
Texture class & 1.50 & $\mathrm{Na}^{+}$ & 6.20 \\
CaCO $\%$ & 0.40 & $\mathrm{~K}^{+}$ & 0.30 \\
Organic matter \% & $\mathrm{CO}_{3}=$ & 0.00 \\
Available nutrients (mg/kg) & 21.3 & $\mathrm{HCO}_{3}^{-}$ & 2.40 \\
$\mathrm{~N}$ & 4.2 & $\mathrm{Cl}^{-}$ & 7.80 \\
P & 62.0 & $\mathrm{SO}_{4}=$ & 2.40 \\
\hline
\end{tabular}

\section{RESULTS AND DISCUSSION}

\section{Peanut yield and its components:}

Data presented in Table (2) indicate peanut yield and its components as affected by different rates of rock phosphate fertilizer and inoculation with cyanobacteria and phosphate dissolving bacteria (PDB). Results revealed that inoculation with cyanobacteria andlor PDB each alone or both in combination increased peanut pods weight, seeds and foliage yields compared to uninoculated treatments. Inoculation with Bacillus only gave significantly higher pods, seeds and foliage yields compared to those inoculated with cyanobacteria only. On the other hand, raising the rate of rock phosphate from 200 up to $600 \mathrm{~kg} \mathrm{fed}^{-1}$ increased in gradual trend significantly pods weight, seeds and foliage yields compared to the treatments received no rock phosphate. However, also the combination of both inoculation and rock phosphate fertilizer at any rate increased significantly these parameters than those received either microbial inoculation or rock phosphate each alone. Relatively, the highest recorded values of 4166.70 , 3367.07 and $3493.30 \mathrm{~kg} \mathrm{fed}^{-1}$ in corresponding to pods, seed and foliage yields due to the treatment received dual inoculation with both cyanobacteria and Bacillus megatherium combined with $600 \mathrm{~kg} \mathrm{fed}^{-1}$ rock phosphate. These high values were not significantly different from those obtained by the treatments received $600 \mathrm{~kg} \mathrm{fed}^{-1}$ rock phosphate combined with Bacillus inoculation. Due to peanut 100-seeds weight, the values were fluctuated between 87.15 and $110.30 \mathrm{~g}$ in corresponding to control treatment (without rock phosphate andlor microbial inoculation) and the treatment of $600 \mathrm{~kg} \mathrm{fed}^{-1}$ rock phosphate combined with dual inoculation with cyanobacteria and Bacillus megatherium. These results are in line with those obtained by Saleh et al. (2000) who reported that phosphorus 
fertilization combined with bacterial inoculation resulted in better nodulation, nitrogenase activity and high increases in yield of soybean and faba bean crops. Recently, there is a great deal of interest in creating novel association between agronomical important plants, particularly the strategic crops such as wheat, maize and peanut and $\mathrm{N}_{2}$-fixing microorganisms including cyanobacteria (Spiller et al., 1993). The heterocystous cyanobacterium Nostoc sp. is usually among characterized cyanobacteria in its ability to form tight association with the roots of these crops and other crops in which they penetrate both roots epidermis and cortical intracellular space (Gantar et al., 1995). Consequently, in this work the treatments inoculated with cyanobacteria andlor dual inoculation with Bacillus megatherium and cyanobacteria in combination with different rates of rock phosphate fertilizer gave peanut seed and foliage yields significantly higher than those obtained without inoculation. Aref and AL-Kassas (2006) explained that the nitrogen released to soil through nitrogen fixed by cyanobacteria inoculated to soil becomes available to the cultivated plants. Moreover, cyanobacteria are known to excrete extra-cellularlly a number of compounds like polysaccharides, peptides, lipids...etc. during their growth in soil, these compounds hold or glue soil particles together in the form of microaggregates and hence improve nutrient availability and consequently enhanced the plant growth parameters.

\section{Nitrogen, phosphorus and potassium contents of peanut seeds and} foliage:

Data in Table (3) indicate the values of N, P and $\mathrm{K}$ contents for both peanut seeds and foliage as affected by different rates of rock phosphate fertilizer and inoculation with cyanobacteria and phosphate dissolving bacteria (PDB). Results revealed that generally, the inoculation of peanut with both cyanobacteria and Bacillus megatherium each applied alone andlor as dual inoculation increased $\mathrm{N}, \mathrm{P}$ and $\mathrm{K}$ contents for both peanut seeds and foliage. Same trend was also observed when the use of biofertilizers was combined with any rate of rock phosphate fertilizer. On the other hand, increasing the rate of rock phosphate fertilizer increased the $\mathrm{N}, \mathrm{P}$ and $\mathrm{K}$ contents for both peanut seeds and foliage compared to those recorded by the non-fertilized treatments. This trend was more pronounced with treatments fertilized with rock phosphate at the rate of $600 \mathrm{~kg} \mathrm{fed}^{-1}$. The corresponding $\mathrm{N}, \mathrm{P}$ and $\mathrm{K}$ values were respectively, arranged as 4.75 .0 .51 and $0.43 \mathrm{mg} \mathrm{kg}^{-1}$ seeds and $1.55,0.17$ and $0.59 \mathrm{mg} \mathrm{kg}^{-1}$ foliage. However, the highest $\mathrm{N}, \mathrm{P}$ and $\mathrm{K}$ values for both peanut seeds. However, the highest $\mathrm{N}, \mathrm{P}$ and $\mathrm{K}$ values for both peanut seeds and foliage were achieved due the combination between $600 \mathrm{~kg} \mathrm{fed}^{-1}$ rock phosphate fertilizer and the dual inoculation with both cyanobacteria and Bacillus megatherium. The corresponding values were 6.86 , 0.71 and $0.56 \mathrm{mg} \mathrm{kg}^{-1}$ seeds against $1.94,0.29$ and $072 \mathrm{mg} \mathrm{kg}^{-1}$ foliage. 
Ahmed, S. M. et al.

Table (2): Effect of different rock phosphate fertilizer levels and inoculation with cyanobacteria andlor phosphate dissolving bacteria on peanut yield and its components

\begin{tabular}{|c|c|c|c|c|c|c|}
\hline \begin{tabular}{|l|} 
Treatments \\
Rate of rock \\
phosphate
\end{tabular} & Inoculation & $\begin{array}{l}\text { Pods } \\
\text { kg/fed }\end{array}$ & $\begin{array}{l}\text { Seeds } \\
\mathrm{kg} / \mathrm{fed}\end{array}$ & $\begin{array}{c}\text { Foliage } \\
\text { kg/fed }\end{array}$ & $\begin{array}{l}100 \text {-seed } \\
\text { Weight (g) }\end{array}$ & Shelling \% \\
\hline \multirow{4}{*}{ Control } & ${ }^{\star} \mathrm{A}$ & 730.42 & 560.00 & 840.00 & 87.15 & 76.67 \\
\hline & B & 1193.30 & 998.70 & 1566.60 & 96.80 & 83.69 \\
\hline & C & 1646.60 & 1386.70 & 1800.00 & 88.90 & 84.22 \\
\hline & d & 1733.30 & 1545.80 & 1893.30 & 104.30 & 89.19 \\
\hline \multirow{4}{*}{$200 \mathrm{~kg} \mathrm{fed}^{-1}$} & A & 1140.82 & 969.70 & 1560.00 & 94.80 & 85.00 \\
\hline & B & 2150.70 & 1821.64 & 1693.30 & 100.20 & 84.70 \\
\hline & C & 2166.70 & 1828.42 & 2200.70 & 102.90 & 84.39 \\
\hline & d & 2966.70 & 2399.98 & 2266.00 & 101.40 & 80.83 \\
\hline \multirow[t]{4}{*}{$400 \mathrm{~kg} \mathrm{fed}^{-1}$} & A & 1650.84 & 1421.70 & 1815.86 & 100.65 & 86.12 \\
\hline & B & 2280.00 & 1928.88 & 1960.00 & 105.60 & 84.60 \\
\hline & C & 2600.00 & 2223.00 & 2533.30 & 106.20 & 85.50 \\
\hline & d & 3466.70 & 2975.47 & 2866.70 & 108.50 & 85.83 \\
\hline \multirow[t]{4}{*}{$\left.600 \mathrm{~kg} \mathrm{fed}^{-1}\right)$} & A & 1988.18 & 1633,49 & 2216.28 & 101.60 & 82.16 \\
\hline & B & 2533.30 & 2045.54 & 2786.70 & 107.20 & 80.75 \\
\hline & C & 3833.30 & 3105.74 & 3206.70 & 108.40 & 81.02 \\
\hline & d & 4166.70 & 3367.07 & 3493.30 & 110.30 & 80.81 \\
\hline \multicolumn{2}{|c|}{$\begin{array}{l}\text { L.S.D. at } 0.05 \\
\text { Rock phosphate } \\
\text { Inoculation } \\
\text { Rock phosphate } x \text { Inoculation }\end{array}$} & $\begin{array}{c}254.35 \\
245.23 \\
3435\end{array}$ & $\begin{array}{c}261.457 \\
275.12 \\
467.40\end{array}$ & $\begin{array}{l}229.04 \\
198.36 \\
315.40\end{array}$ & & \\
\hline
\end{tabular}

${ }^{*} A=$ uninculated (control) $\quad B=$ Cyanobacteria $\quad C=$ Bacillucs megatherium $\quad D=B+C$

Table (3): Effect of different rock phosphate fertilizer levels and inoculation with cyanobacteria andlor phosphate dissolving bacteria on NPK-uptake by peanut seeds and foliage

\begin{tabular}{|c|c|c|c|c|c|c|c|}
\hline \multicolumn{2}{|l|}{ Treatments } & \multicolumn{3}{|c|}{$\begin{array}{c}\text { Seeds } \\
\left(\mathrm{mg} \mathrm{kg}^{-1}\right)\end{array}$} & \multicolumn{3}{|c|}{$\begin{array}{c}\text { Foliage } \\
\left(\mathrm{mg} \mathrm{kg}^{-1}\right)\end{array}$} \\
\hline $\begin{array}{|lrl|}\text { Rate of } & \text { rock } \\
\text { phosphate } & \\
\end{array}$ & Inoculation & $\mathbf{N}$ & $\mathbf{P}$ & K & $\mathbf{N}$ & $\mathbf{P}$ & K \\
\hline \multirow{4}{*}{ Control } & ${ }^{*} A$ & 4.20 & 0.30 & 0.39 & 1.51 & 0.12 & 0.59 \\
\hline & B & 5.00 & 0.34 & 0.42 & 1.70 & 0.14 & 0.63 \\
\hline & C & 4.45 & 0.44 & 0.43 & 1.54 & 0.16 & 0.60 \\
\hline & D & 5.12 & 0.49 & 0.45 & 1.82 & 0.18 & 0.66 \\
\hline \multirow{4}{*}{$200 \mathrm{~kg} \mathrm{fed}^{-1}$} & $\mathbf{A}$ & 4.31 & 0.35 & 0.40 & 1.52 & 0.13 & 0.58 \\
\hline & B & 5.16 & 0.42 & 0.44 & 1.73 & 0.16 & 0.65 \\
\hline & C & 4.88 & 0.52 & 0.50 & 1.62 & 0.19 & 0.59 \\
\hline & D & 5.88 & 0.58 & 0.54 & 1.85 & 0.21 & 0.67 \\
\hline \multirow{4}{*}{$400 \mathrm{~kg} \mathrm{fed}^{-1}$} & $\mathbf{A}$ & 4.51 & 0.43 & 0.40 & 1.55 & 0.14 & 0.58 \\
\hline & B & 5.92 & 0.50 & 0.46 & 1.74 & 0.20 & 0.67 \\
\hline & C & 5.62 & 0.58 & 0.49 & 1.64 & 0.22 & 0.60 \\
\hline & D & 6.65 & 0.63 & 0.54 & 1.88 & 0.25 & 0.68 \\
\hline \multirow{4}{*}{$600 \mathrm{~kg} \mathrm{fed}^{-1}$} & $\mathbf{A}$ & 4.75 & 0.51 & 0.43 & $1-55$ & 0.17 & 0.59 \\
\hline & B & 6.76 & 0.60 & 0.52 & 1.77 & 0.22 & 0.67 \\
\hline & C & 5.78 & 0.65 & 0.52 & 1.66 & 0.25 & 0.62 \\
\hline & D & 6.86 & 0.71 & 0.56 & 1.94 & 0.29 & 0.72 \\
\hline
\end{tabular}

The present results are confirmed by those achieved by EL-Sawy et al. (2006) who found that dual inoculation with cyanobacteria and rhizobcteria 
increased significantly $\mathrm{N}, \mathrm{P}$ and $\mathrm{K}$ contents for peanut seeds over uninoculated plants. They explained that both cyanobacteria and rhizobacteria fix nitrogen, excrete organic acids that help in dissolving both insoluble soil phosphorus and potassium, which in turn be made available to the cultivated plants. Mandal et al. (1999) reported that cyanobacteria play an important role in soil phosphorus transportation; they explained that cyanobacteria, like P-solubilizing bacteria, are known to have the ability to mobilize bound phosphate. They have been shown to solubilize insoluble $(\mathrm{Ca})_{3}\left(\mathrm{PO}_{4}\right)_{2}, \mathrm{Al} \mathrm{PO} 4, \mathrm{Fe} \mathrm{PO}_{4}$ and hydroxyapatite in soil, sediments or in pure cultures. There are mainly two hypotheses, proposed by two groups, to explain how cyanobacteria solubilize such bound phosphates. One group suggested that they might synthesize a chelator (chelators?) for $\mathrm{Ca}^{2+}$ and then liberate phosphate into the soil. The other group suggested that $\mathrm{H}_{2} \mathrm{CO}_{3}$ and other organic acids released by cyanobacteria during their growth cold solubilize $\mathrm{P}$ from the insoluble $\mathrm{P}$ form in soil. They also reported another opinion and believed that once $\mathrm{PO}_{4}$ librated from $\mathrm{Ca}$ due to the action of $\mathrm{H}_{2} \mathrm{CO}_{3}\left\{\mathrm{Ca} 3\left(\mathrm{PO}_{4}\right)_{2}+2 \mathrm{H}_{2} \mathrm{CO}_{3}=2 \mathrm{CaHPO}_{4}+\mathrm{Ca}\left(\mathrm{HCO}_{3}\right)\right\}$, the $\mathrm{PO}_{4}{ }^{3+}$ is taken up by the growing cyanobacteria cells for their nutrition. After completing their growth cycle, when the cells undergo lysis the cell bound $\mathrm{PO}_{4}{ }^{3+}$ is released to the soil and becomes available to the plants on mineralization. On the other respect, Hanna et al. (2004) also attributed the increases in N, P and K uptake of wheat inoculated with cyanobacteria to the ability of cyanobacteria inoculant to improve the availability of nitrogen in soil through nitrogen fixation and also its ability to dissolve both insoluble phosphate and potassium.

Soil total count of bacteria, actinomycetes and fungi:

Data in Table (4) indicate the values of soil total count of bacteria, actinomycetes and fungi as affected by different rates of rock phosphate fertilizer and inoculation with cyanobacteria and phosphate dissolving bacteria (PDB) compared to uninoculated treatments. Results pointed out that in all tested treatments, increasing the time of soil sampling from initial to flowering time increased the count of all tested microorganisms, while at harvest the counts started to decline. Due to the effect of the tested treatment of either microbial inoculation or rock phosphate rates and their combination, initially, no definite trend was detected, since the count of bacteria, actinomycetes and fungi, slightly increased in response of these treatments. However, at flowering stage, generally, the inoculation with either cyanobacteria or Bacillus andlor their combination increased the count of all tested microorganisms compared to those recorded by uninoculated treatments. Same behavior was observed for the count of bacteria, actinomycetes and fungi, when they influenced by different rates of rock phosphate fertilizer. Usually, the dual inoculation with cyanobacteria and Bacillus in combination with any rate of rock phosphate fertilizer resulted in higher count of bacteria, actinomycetes and fungi than those obtained by the treatments received either microbial inoculation or different rates of phosphorus fertilizer each applied alone. The highest count of bacteria, actinomycetes and fungi was achieved by the use of rock phosphate fertilizer at the rate of $600 \mathrm{~kg} \mathrm{fed}^{-1}$ in combination with dual inoculation with both cyanobacteria and Bacillus at the flowering time. The corresponding count numbers were $127.67,86.00$ and $65.67 \mathrm{cfu} \mathrm{g}^{-1}$ dry soil. 
Ahmed, S. M. et al.

T4

8132 
In this Approach, this trend due to the microorganisms count is true because at the flowering stage, plants reached their maximum physiological activity that increased the root exudates in the rhizosphere area and consequently in soil, which in turn promote the microbial proliferation in soil and increased their numbers. These conditions are not saved in the other two tested stages (initial and harvest).

For Soil microbial community, the used treatments led increase the number of the tested microorganisms, i.e., bacteria, actinomycetes, fungi and cyanobacteria at peanut flowering stage compared to both initial and harvest stages. This trend is true because at the flowering stage, plants reached it maximum physiological activity that increased the root exudates in the rhizosphere area, which in turn promote the microbial proliferation in soil and increased their number. These conditions are not saved in the other two tested stages. AL- Kassas, (2002) Reported that wheat Inoculation with the nitrogen fixing diazotrophs including cyanobacteria increased the soil Azospirilla and other soil microbial population including fungi, actinomycetes, Azotobacter and cyanobacteria. The decomposition of the inoculated cyanobacteria in soil led to accumulate the organic matter in soil, which, is consequently increased the soil microbial population (Mandal et al., 1999).

From the abovementioned results, it could be recommended that the integration between cyanobacteria phosphate dissolving bacteria inoculation in presence of rock phosphate as a cheap natural source of phosphorus fertilizer in peanut cultivation under sandy soil condition is more beneficial than the use of any of them individually. This integration also helps in the fast solubilization of the insoluble phosphate found in rock phosphate that may lead to reduce the cost and the environmental pollution due to the extensive use of the mineral fertilizers. However, this work needs to be repeated with peanut and some other cereal crops to be confirmed and actually recommended. This microbial inoculation/rock phosphate integration helps in the fast solubilization of the insoluble phosphate found in rock phosphate that may lead to reduce the cost and the environmental pollution due to the extensive use of the mineral fertilizers.

\section{REFERENCES}

Abdel-Wahab, A. F. M; A. M. Biomy and W. M. El-Farghal (2003). Effect of some natural soil amendments on biological nitrogen fixation, growth and green yield of pea plant grown on sandy soil. Fayoum J. Agric. Res. and Develop., 17: 47-54.

AL- Kassas, A. R. (2002). Production of wheat and its quality in newly reclaimed lands. Ph. D. Thesis, Fac. of Agric. Al-Azhar University, Cairo, Egypt.

Allen, U. N. (1959). Experiments in soil Bacteriology. $1^{\text {st }}$ Ed. Burges pub. Co. USA.

Aref Elham, M., and A. R. AL-Kassas (2006). Cyanobacteria inoculation as nitrogen source may substitute partially mineral nitrogen in maize production. J. Agric Sci, Mansouea Univ., 31: 5367 - 5378.

Chapman, H.D. and P. E. Pratt (1961). Methods of analysis for Soils, Plant and Water. Univ. of California, Division of Agric. Sc. 
Conacher, J. and A.Conacher (1998). Organic farming and the environment with particular reference to Australia. A review. Biol. Agric. \& Horticulture.16: 145-171.

EL-Sawy, W. A.; G. A. A. Mekhemar and B. A. A. Kandil (2006). Comparative assessment of growth and yield responses of two peanut genotypes to inoculation with Bradyrhizobium japonicum conjugated with cyanobacteria or rhizobacteria. Minufiya J. Agric RES., 31(4): 1031 1049.

El-Habbasha, S. F.; A. A. Kandil; N. S. Abu-Hagaza; A.K. Abd El-Haleem, M.A. Kalafallah and T.Ch. Behairy (2005). Effect of phosphorus levels and some biofertilizers on dry matter, yield and yield attributes of groundnut. Bull. Fac. Agric. Cairo Univ., 56: 237-252.

Gantar, M., Rowell, P. and Kerby, N. W. (1995). Role of extracellular polysaccharides in the colonization of wheat (Triticum vulgarie L.) roots by $\mathrm{N}_{2}$-fixing cyanobacteria. Biol. Fertl. Soils. 19: 41-48.

Gomez, K. A. and A. A. Gomez (1984). Statistical procedures for Agricultural Research., (2 ${ }^{\text {nd }}$ ed.). 20 - 29.

Hanna Mona, M.; Elham M. Aref and F. M. Ghazal (2004). Effect of cyanobacteria-wheat association on wheat production and soil fertility. J. Agric Sci., Mansoura Univ., 29: 2941 - 2948.

Hedege, D. M, B. S. Dwivedi and S. N. Ssudhakara Baubu. (1999). Biofertilizers for cereal production in India. A review. Ind. J. Agric Sci., 69: $73-83$

Hussein, A. H. A.; W. Kadry; R. F. Dessoky; A. M. Hassanein and M. A. ElDeeb (1993). Effect of different levies and application methods of phosphorus and some micronutrients on faba bean in calcareous soil. Egypt. J. Appl. Sci., 8: 387-397.

Jackson, M. L. (1976). Soil Chemical Analyses.Constable. Co. Lt., London,UK.

Jensen, E. S. and H. Hauggaard (2003). How can increased use of biological $\mathrm{N}_{2}$-fixation in agriculture benefit the environment ?. Plant and Soil. 252: 177-186.

Knany, R. E.; A. M. Massoud and Y. B. El-Waraky (2004). Comprative study between biofertilization and sulphur on availability of added phosphorus to gaba bean plants under high $\mathrm{pH}$ soil conditions. J. Agric. Sci. Mansoura Univ., 29: 4801-4809.

Mandal, B. K., P. L. G. Vlek and L. N. Mandal. (1999). Beneficial effects of blue-green algae and Azolla, excluding supplying nitrogen, on wetland rice fields: a review. Biol. Fertl. Soils. 28: 329-342.

Martin, J. P. (1950). Use of rose Bengal and streptomycin in the plate method for estimating soil fungi. Soil Sci., 69 (3): 215-233.

Mekhemar, G. A. A; F. M. Ismail, F. Sh. F. Badawi and B. A. A. Kandil (2007). Response of Peanut (Arachis hypogaea L.) to co-inoculation with Bradyrhizobium spp. and phosphate dissolving bacteria under different levels of phosphorus fertilization in sandy soils. Agric. Res. J., Suez Canal Univ., 7 (1):1-8.

Miller, R. W. and R. L. Donahue (1995). Soils in our environment. Prentic Hall, Engle Wood Cliffs, 649 pp.

O'Hara, G.W.; B. Notakom and M. J. Dilworth (1988). Mineral constraints to nitrogen fixation. Plant and Soil. 108: 93-110. 
Page, A. L. (1982). Methods of soil analysis. Part I. Physical properties and Part II. Chemical and microbiological properties ( $2^{\text {nd }}$ ed.). Amer. Soc. Agron. In Soil Sci. Soc. Amer. Inc. Madison Wisconsin, USA, Chapter 12, 199-223.

Rashid, A. and j. Ryan (2004). Micronutrients constraints to crop production in soils with Mediterranean -type characteristics: A review. J. Plant Nutr., 27(6): 959- 965.

Saleh, S. A.; M. A. El-Deeb and A. A. Ragab (2000). Response of faba bean (Viciae faba L.) to Rhizobium inoculation as affected by nitrogen and phosphorus fertilization. Bull. Fac. Agric., Cairo Univ., 51: 17-30.

Spiller, H., Stallings, W., Woods, T. and Gunasekaran, M.(1993). Requirement for direct association of ammonia-excreting Anabaena variabilis mutant (SA-1) with roots for maximal growth and yield of wheat. Appl. Microbiol. Biotechnol. 40: 557-566.

Van Schreven, D. A. (1958). Methods used in the Netherlands for the production of legume inoculants. In: Nutrition of the legumes (E.G.H. Allsowth, ed.). Bottenworths, London, UK. 328 D-333.

Venkataraman, G. S. (1972). Biofertilizer and rice cultivation.Today and Tomorrow, New Delhy, India. pp.81-84.

Williams, S. T. and F. L. Davis (1965). Use of antibiotics for selected isolation and enumeration of actinomycetes in soil. J. Gen. Microbiol., 38: 251261.

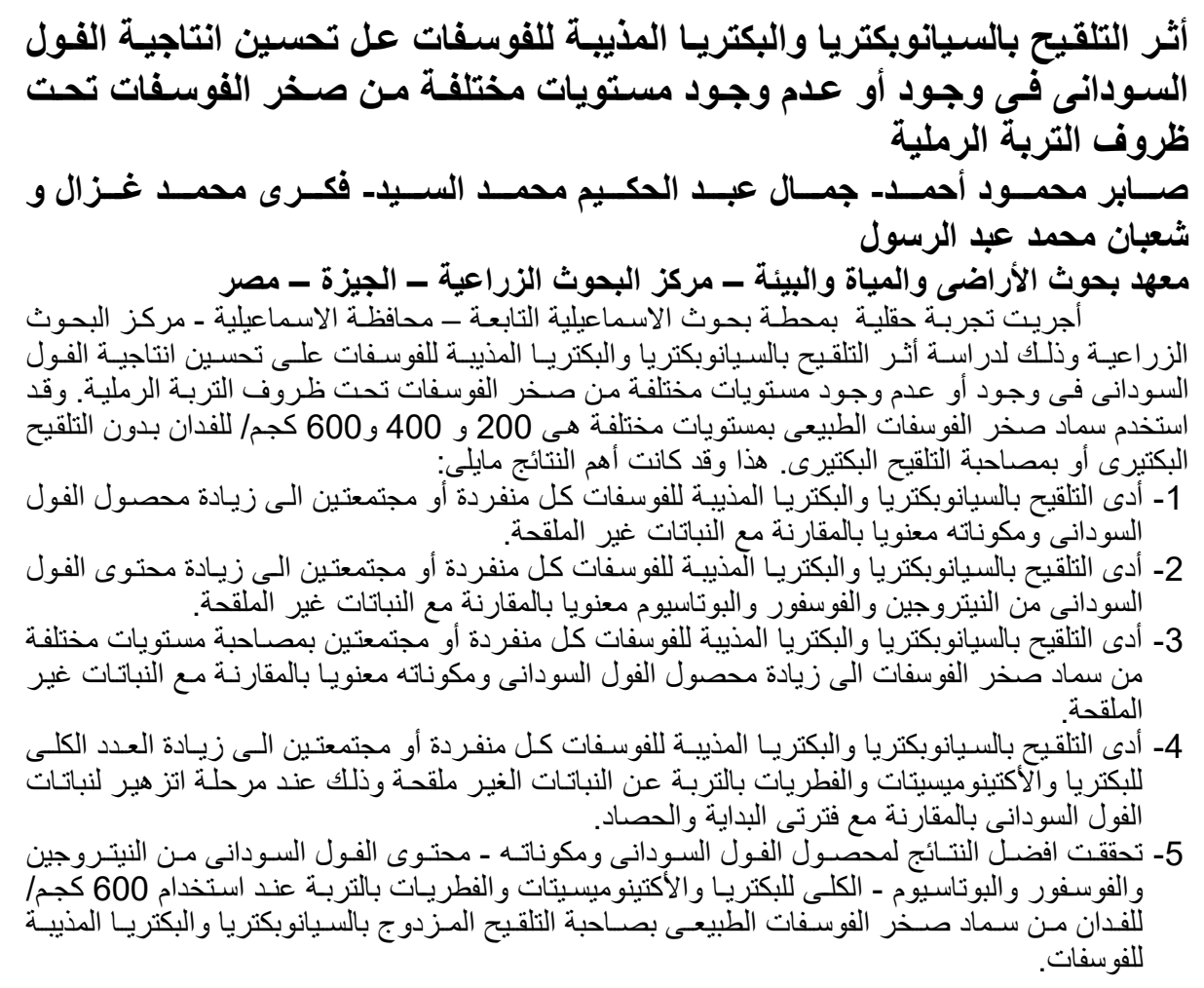


Ahmed, S. M. et al.

8136 
Table (4): Effect of different rock phosphate fertilizer rates and inoculation with cyanobacteria and lor phosphate dissolving bacteria on total bacteria , Actinomycetes and fungi count in soil at different growth stages of peanut (cfu = Colony formed $\mathrm{per}$ unit $/ \mathrm{g}$ soil)

\begin{tabular}{|c|c|c|c|c|c|c|c|c|c|c|}
\hline \multicolumn{2}{|l|}{ Treatments } & \multicolumn{3}{|c|}{$\begin{array}{l}\text { Total count bacteria } \\
\text { (cfu g soil }\end{array}$} & \multicolumn{3}{|c|}{$\begin{array}{l}\text { Total count Actinomycetes } \\
\text { (cfu g soil }^{-1} \text { ) }\end{array}$} & \multicolumn{3}{|c|}{$\begin{array}{l}\text { Total count fungi } \\
\text { (cfu g soil }{ }^{-1} \text { ) }\end{array}$} \\
\hline \begin{tabular}{|l|} 
Rock \\
phosphate \\
fertilizer rate
\end{tabular} & Inoculation & $\begin{array}{c}\text { Initial time } \\
\times 10^{5}\end{array}$ & $\begin{array}{c}\text { Flowering } \\
\text { stage } \\
\mathrm{X} 10^{5}\end{array}$ & $\begin{array}{c}\text { Harvest } \\
\text { stage } \\
\mathrm{X} 10^{5}\end{array}$ & $\begin{array}{l}\text { Initial time } \\
\times 10^{3}\end{array}$ & $\begin{array}{c}\text { Flowering } \\
\text { stage } \\
\times 10^{3}\end{array}$ & $\begin{array}{c}\text { Harvest } \\
\text { stage } \\
X 10^{3}\end{array}$ & $\begin{array}{c}\text { Initial time } \\
\times 10^{4}\end{array}$ & $\begin{array}{l}\text { Flowering } \\
\text { stage } \\
\times 10^{4} \\
\end{array}$ & $\begin{array}{c}\text { Harvest } \\
\text { stage } \\
\times 10^{4} \\
\end{array}$ \\
\hline \multirow{4}{*}{ Control } & A & 26.00 & 30,00 & 13.00 & 8.00 & 9.33 & 5.00 & 4.00 & 8.67 & 5.38 \\
\hline & B & 26.00 & 36.67 & 16.00 & 8.33 & 18.67 & 6.00 & 5.00 & 22.33 & 8.67 \\
\hline & C & 28.67 & 39.33 & 19.00 & 8.00 & 20.33 & 10.33 & 5.33 & 25.00 & 9.00 \\
\hline & D & 28.67 & 54.00 & 21.60 & 8.00 & 32.00 & 17.33 & 5.33 & 27.67 & 12.33 \\
\hline \multirow{4}{*}{$200 \mathrm{~kg} \mathrm{fed}^{-1}$} & A & 27.00 & 39.00 & 15.00 & 9.33 & 12.67 & 5.12 & 4.12 & 10.12 & 6.00 \\
\hline & B & 29.00 & 54.00 & 19.33 & 11.00 & 48.33 & 9.00 & 5.00 & 27.33 & 7.00 \\
\hline & C & 31.67 & 60.67 & 24.00 & 12.00 & 59.67 & 14.33 & 5.67 & 30.31 & 7.33 \\
\hline & D & 32.67 & 87.70 & 27.00 & 12.67 & 61.00 & 22.67 & 6.00 & 45.67 & 16.33 \\
\hline \multirow{4}{*}{$400 \mathrm{~kg} \mathrm{fed}^{-1}$} & A & 27.00 & 44.00 & 19.66 & 9.66 & 15.33 & 5.14 & 4.67 & 14.33 & 6.67 \\
\hline & B & 30.67 & 61.00 & 26.00 & 11.33 & 47.33 & 10.33 & 5.00 & 40.67 & 8.33 \\
\hline & C & 31.00 & 78.00 & 29.67 & 1233 & 65.67 & 19.67 & 6.00 & 50.33 & 15.00 \\
\hline & D & 33.00 & 104.00 & 31.00 & 12.67 & 73.67 & 30.67 & 6.67 & 52.33 & 20.67 \\
\hline \multirow{4}{*}{$600 \mathrm{~kg} \mathrm{fed}^{-1}$} & A & 27.00 & 46.00 & 22.00 & 986 & 18.67 & 5.33 & 4.67 & 15.67 & 6.67 \\
\hline & B & 28.00 & 71.67 & 23.33 & 12.00 & 49.00 & 20.00 & 6.67 & 42.67 & 9.00 \\
\hline & C & 29.33 & 94.00 & 27.67 & 11.33 & 67.67 & 26.00 & 6.67 & 59.00 & 18.00 \\
\hline & D & 31.0 & 127.67 & 43.00 & 12.67 & 86.00 & 38.33 & 7.00 & 65.67 & 21.67 \\
\hline
\end{tabular}

${ }^{\star} \mathrm{A}=$ uninculated (control)

$\mathrm{B}=$ Cyanobacteria $\quad \mathrm{C}=$ Bacillucs megatherium $\quad \mathrm{D}=\mathrm{B}+\mathrm{C}$ 